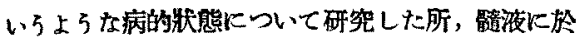
ては緗胞數は正常值飞あるに拘らず，內耳夜內とは 僅少ながら正常より增加が認められるのたある。然

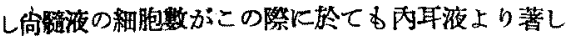

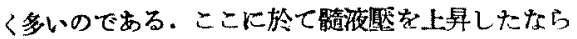

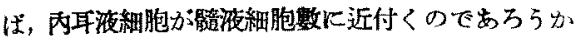

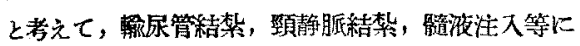

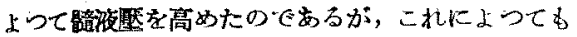
內耳液丙細胞數は正常上り極めて僅か飞增加子る が，链夜內細胞數とは著明な差がある。それでは䯣 液に非炎症性に淋巴球墂加を惹起せしめた時にはど ろなるであららかと考えて Swift Ellis 氏法及びど タミン $B_{1}$ 檤液內注入洗を試みたのであるが，これ 等の方法に上る輕度の淋巴球檑多に上つては，內耳

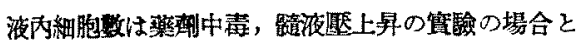
同程度の堵加であつて，僅かに正常値より多いのみ で嘎夜とは著明な差がある。

以上の蛽驗からして踣夜內細胞數が正常でも身体

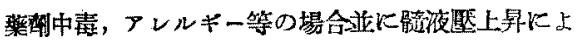

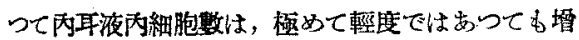

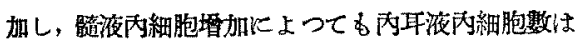
同程度に埥加するるのである。ここに於て內耳液と

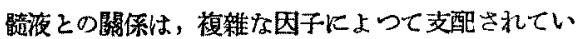

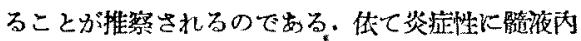
細胞增多营起したならば，以上の筫驗の三りの因

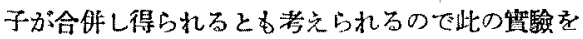
行つたのであるが，これに上ると內耳液細胞數は極

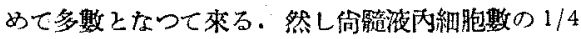
〜1/10程度であつて，淤して同程度とはならないの

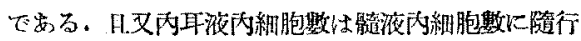

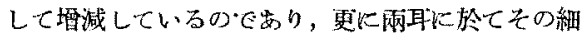
胞数が全く同じであるのでるる，それでは全身的障

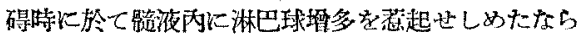

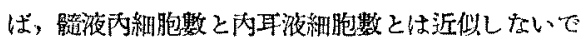

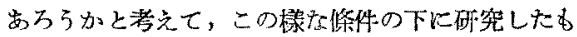

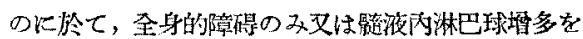
起したのみの場合と差異がないのである。

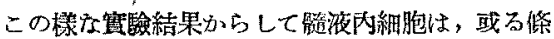
件の下には內耳液に移行するけれどす，決して自由 に交通移行与尚わのでないし，その狀態は一定のる

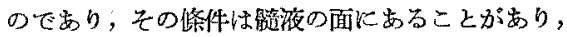
踖液と內耳液との交通路の面飞岁るとがあること

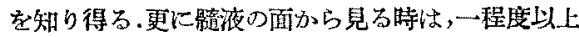

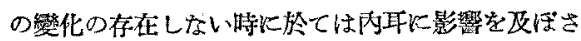

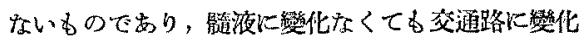
ある際は內耳液に影留与るあのであることを知る。

\title{
T. KAJI, M.D : A EXPERIMENTAL STUDY ON THE MECHANISM OF CHANGES LABYRINTHINE FLUID
}

\section{內耳液の變動機轉に關す万實驗的研究}

\section{第 2 篇 蝸牛款導水管の機能に關する實驗的研究}

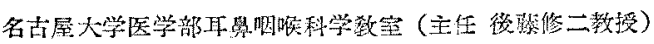

曹攻生加治俊信

\section{第1算藉䇾}

第 1 篇飞於汁万研究に於て䒃液と队耳液との交通

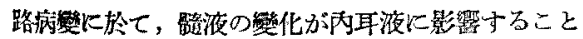
を考えられたのでるるか，その交通路としての蝸牛

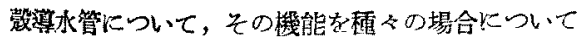

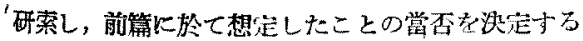
ために本蛙驗行つた.

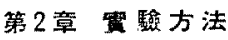

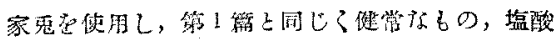

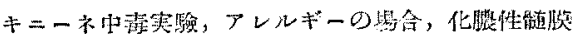

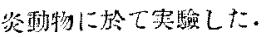

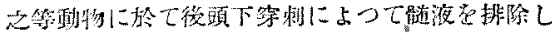

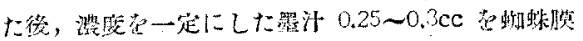

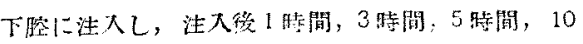




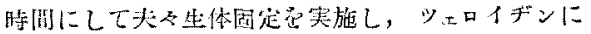

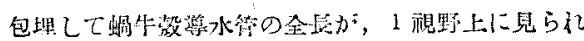

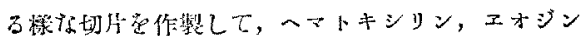

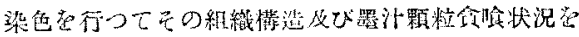

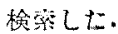

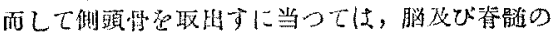

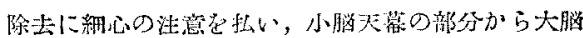

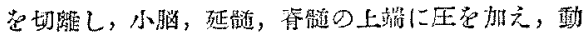

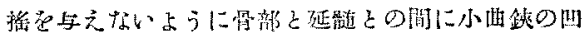

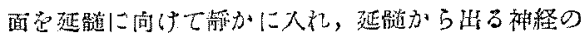
下位の6のから切断し，夷第に上位の6のに欢び内

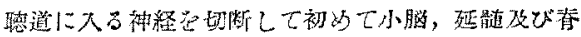

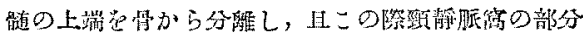

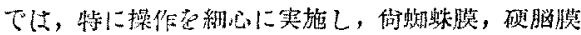

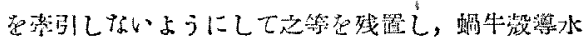

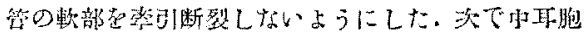

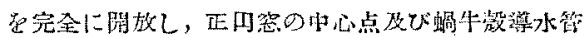

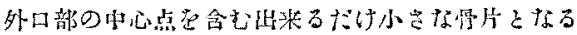
橴にした。

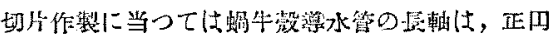

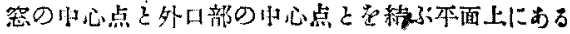

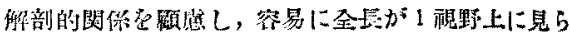

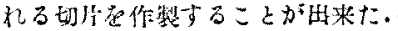

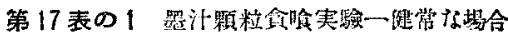

\begin{tabular}{|c|c|c|c|c|c|}
\hline 䣦 勒 品 & 1 & 2 & 3 & 4 & 5.617 \\
\hline 阿定论の释通瞅 & 時期 & 1 & 3 & 3 & 510110 \\
\hline
\end{tabular}

第 17 表の 2 墨汁顆粒拿喰実驗一塩酸

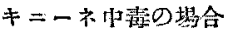

\begin{tabular}{|c|c|c|c|c|c|c|c|}
\hline 㔚 & 物 落 号 & 1 & 2 & 3 & 4 & 5 & 6 \\
\hline $2 \%$ & 每 1 病白 & 2.0 & 3.0 & 3.0 & 3.0 & 4.0 & 3.0 \\
\hline 形相 & 筑2病日 & 2.5 & 4.0 & 3.0 & 5.0 & 5.0 & 5.0 \\
\hline * & 筑 3 疮日 & 3.0 & 6.0 & 5.0 & 5.0 & 7.0 & 8.0 \\
\hline 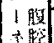 & 的 4 积 & 4.0 & 8.0 & 7.0 & 8.0 & 8.0 & 10.0 \\
\hline 水花 & 和 5 & 5.0 & 10.0 & 10.0 & 110.0 & 10.0 & 10.0 \\
\hline 灕财 & 符 6 脑几 & 7.0 & 12.0 & 12.0 & 10.0 & & 10.0 \\
\hline & 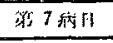 & 8.0 & 12.0 & & & & 10.0 \\
\hline & 住入独口 & 7 & 7 & 6 & 6 & 5 & 7 \\
\hline & & & 1 & 3 & 3 & 5 & \\
\hline
\end{tabular}

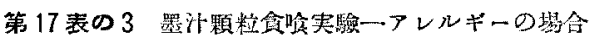

\begin{tabular}{|c|c|c|c|c|c|c|c|}
\hline 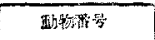 & 1 & 2 & 3 & 4 & 5 & 6 & 7 \\
\hline 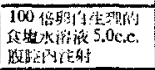 & 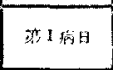 & 1 积a & 第 1 执日 & 程 1 瘳日 & 独 1 病日 & 策 1 积日 & 管 1 形日 \\
\hline 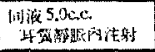 & 籍4 街日 & 然 5 H & 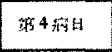 & 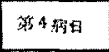 & 第5 松日 & 邪5 稆口 & 施5 \\
\hline 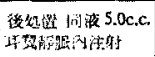 & 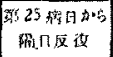 & 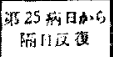 & 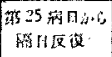 & 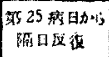 & 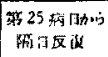 & 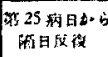 & 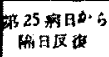 \\
\hline 闵彼胜数 & 3 & 5 & 5 & 3 & 3 & 5 & 5 \\
\hline 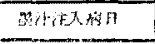 & 29 & 33 & 33 & 29 & 29 & 33 & 33 \\
\hline 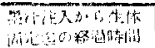 & 1 & 1 & 3 & 3 & 5 & 10 & 10 \\
\hline
\end{tabular}

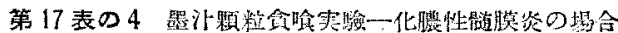

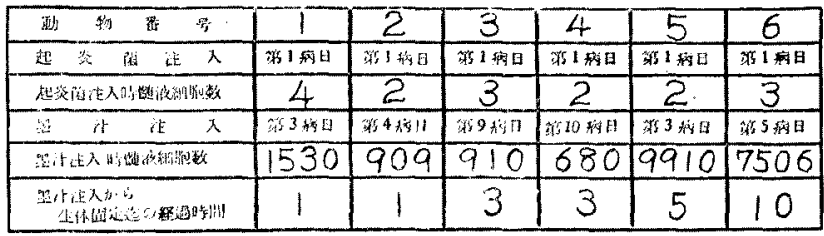

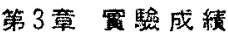

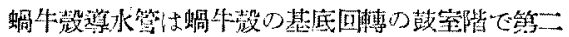

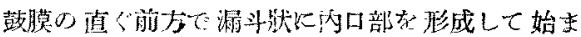

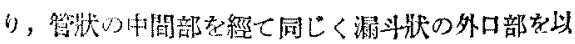

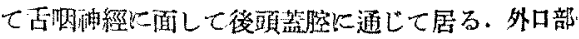

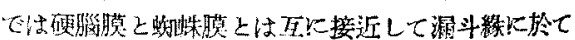




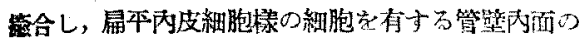

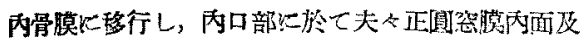

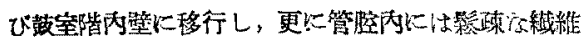

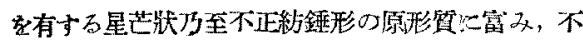

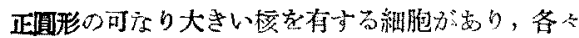

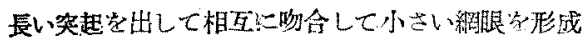

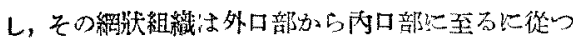

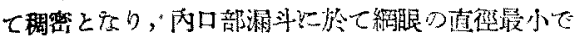

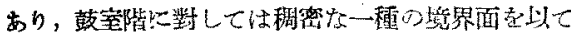
臨んで居るが Waltner の䊈える特殊櫵造わしのた は灾い。

等 1 項 正常勳物の場合（縈17 表の1）

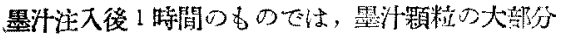
のものは絧艮の中に包有されて居り，殊に外口部と は多數が勧簇して認められ，中間部から内口部に向

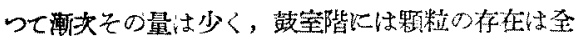

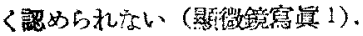

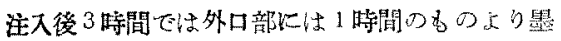

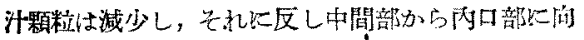
つは顆粒は增加しているのか認かられる。然し矢

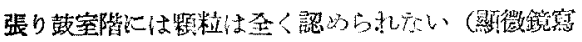
眞 2).

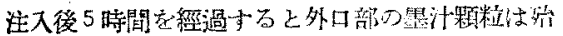

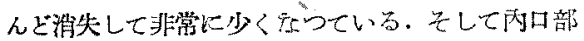

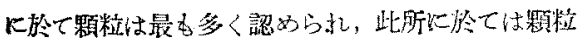

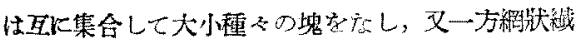

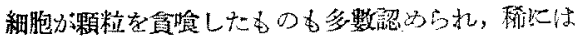

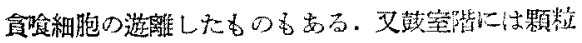

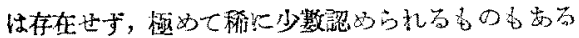

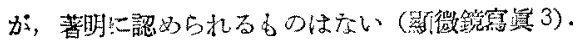

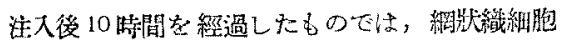
の颗粒を真哈したものが多整となり，これた反し紨

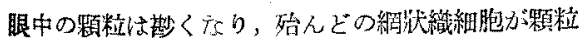

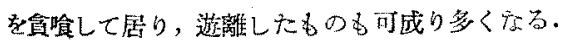

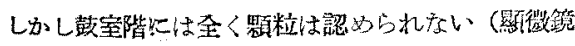
舁宣 4).

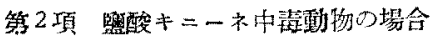

(管 17 表の 2)

墨汁注入後 1 時間のものでは樂水管外口部には，

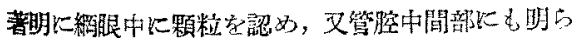
加に颗精を認的るが，內口部には認かられる埸合と

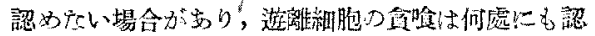

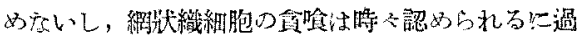

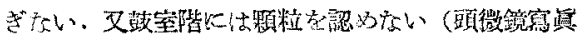
5).

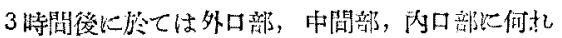

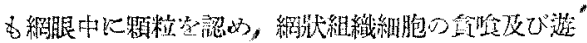

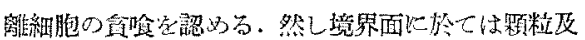

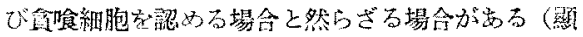
微鏡撺瀆 6).

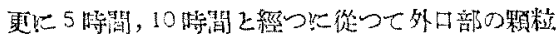

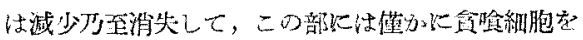

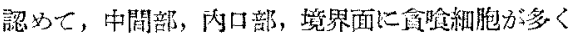

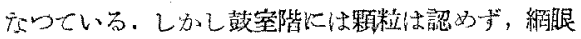

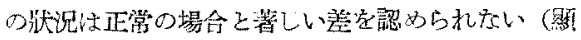
微鏡窞道7.8).

\section{第了俱 フレルギ一㽖物の場合} (管 17 裴の3)

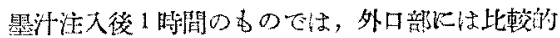

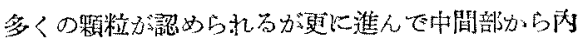

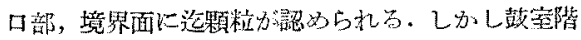
飞は全く認めら机い，中閒部方ら內口部の一部に

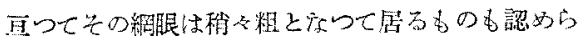

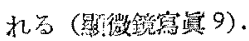

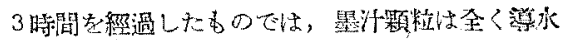

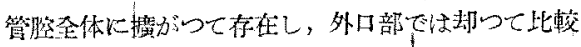

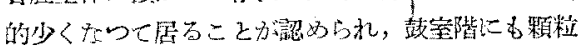

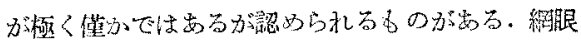

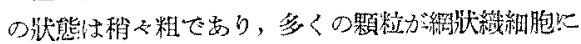

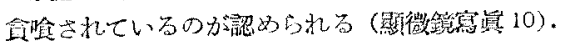

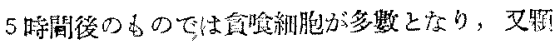

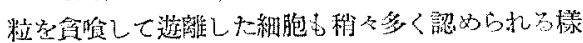

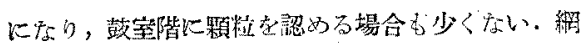

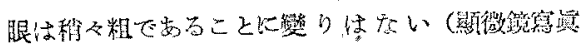
11).

更に進んて10時間を經過すると，維状織細胞す

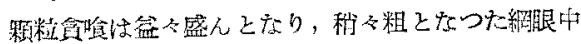

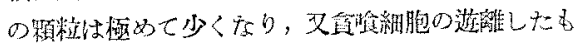

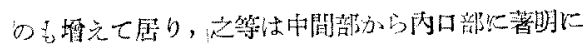

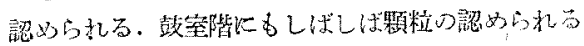

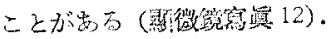




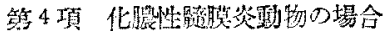

(算12 表の4)

墨汁注入後 1 时間で碩粒は破燷して非常に粗とな

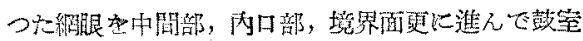

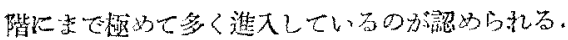

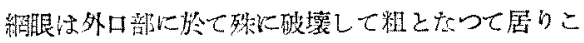

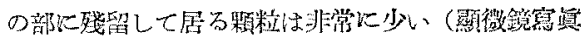
13).

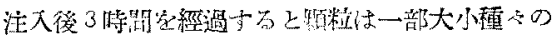

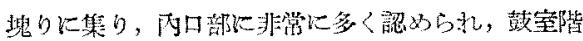

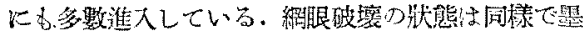

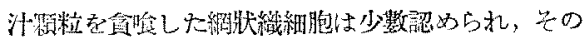

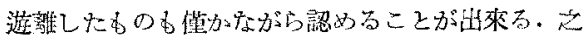

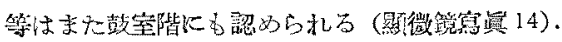

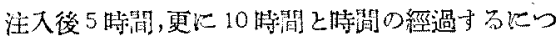

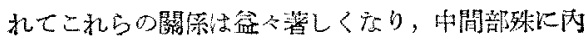

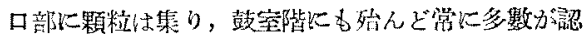

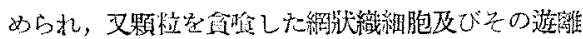
細胞娄比較的に多くなり，これ等は又都室階にも多

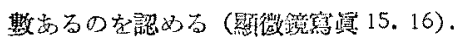

\section{第 4 章 本篇の總括}

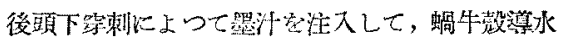

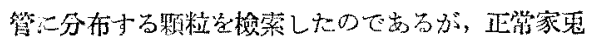

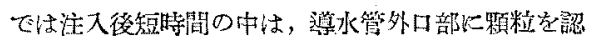
わ，時䦌の經過飞共心中聞部，內口部或は更に洗界

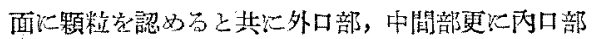

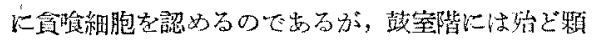

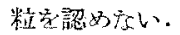

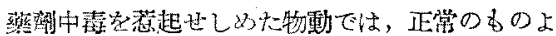

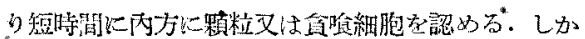
乙鼓空墔には等ど認めない。

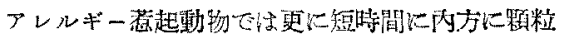

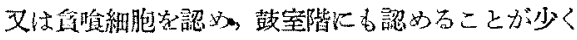
ない。

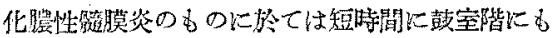
多數の颗精总認め，顆粒攻び会哈細胞は境界面，内 口部に著しく，外口部には少い。この關倸は時間の 經過と其火著明で岁，

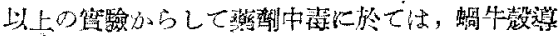

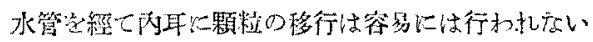

のであることが知られかが，正常の場合よりは早期 飞颗粒が內方に移動し得ることが知られ，アレルキ

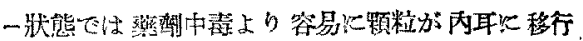

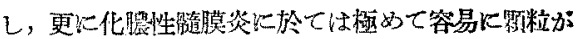
内耳移躭し得るすのであることが制る。

それてはこ扎何によつて起るのであららか。こ

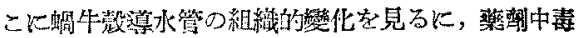
に於ては正常と确ど差累が㒛められないが，アレル ギーの場合に於ては絟䀶が粗となつてい尚所があ

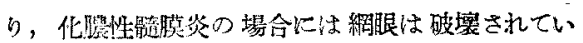

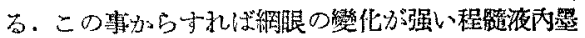
汁は，內耳に移行し易いのである.そして組織的数

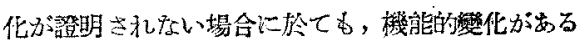
嚗合比も，正赏の場合上り墨汁性內氏移行し易い 子のであることが制る。

\section{第 5 章 全策の總括並びに考按}

さき㴹路生理についての業㣱の多數發表される

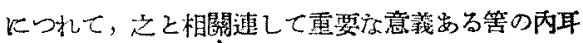
液について，こ机の何物であるか在究め上了とし て，1910 年酮受の烧ドェシャーテ (1913 年)，キル ベルト（1914 年），フライシェマン（1918年）等多 數の學者によつて，はじめ主にその物理化學的性狀 の研究に㖕手され，断片的にその成禎を報告して居

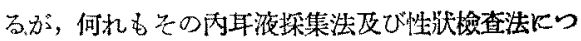
いての記載が明磪でい憾みがあり，疑間をさしは 导余地がないわけではなかったのでるるがここの

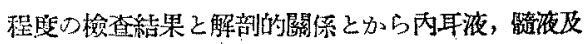
び腿房水は極めて近似のものである考えられて居 ot.

我が國では1915 年才根喜一は, 無菌的操作によ つて得た內耳淋巴腹について秘菌力の有無を检查 し，险性であつたと唱えたのを刎めとして，1923年

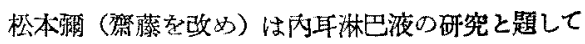

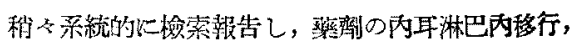
内耳淋巴の化疫体殊飞溶血素について，内耳淋の 性㭊につて, 內耳淋巴の緗胞學的研究, 內耳湘巴

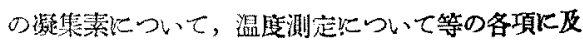

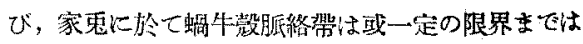

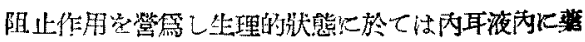
洲の移行，抗体の出現は認められず，その機能一度 


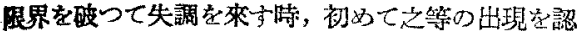

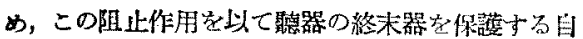

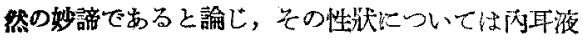

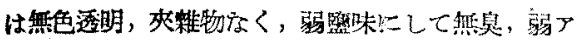

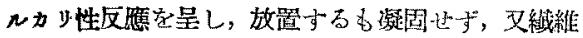
素塊作ることなく，その粘秵度は平均 1.05 (へス

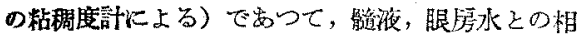

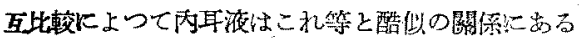

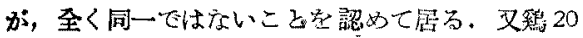

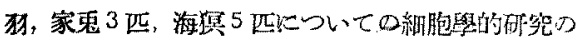
棓果, 內耳液中には㱠儿ど細胞成分学思出さ市いの が普通で，稀に淋巴球を見出すことが要万とし，留造

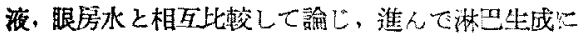

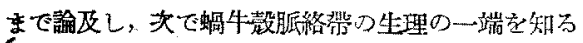
ために內耳液內㠜勧素について研究し，健態動物に

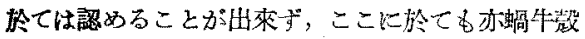

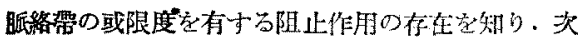
で温度測定を行つて居る。

1928 年海江且純本亦鮫類の内耳液について 外觀,

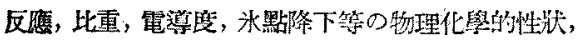
主なる有機成分化ついて检菜し，1933 年高原离三

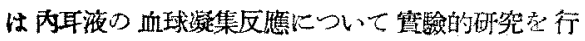

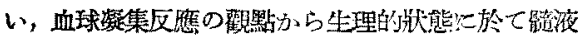
乙眼居水忏近似であって，寒性自家，同程，罢種の

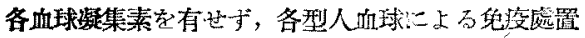

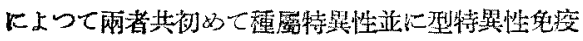

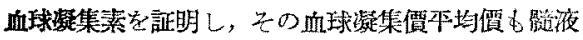

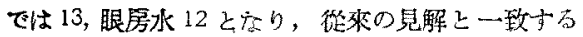
が，ひとり內耳液たシ十は生理的趿態於て寒性自家 血球凝集素を有し，且血球凝集借平均聩 20 にてて 前二者とは暲り從來の見解とは明らか下速つて居吉

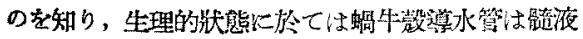
と內耳液との自由て直接的な交通路としての学味中

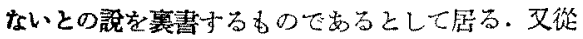

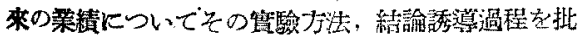

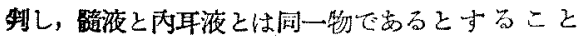
は，早計の識を身れないと6言つて居る。1936年

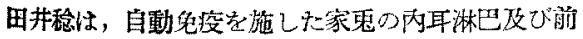
房水中に出現し得る抗体について㫵究した．以上の 諸家の研究に上つて內耳液は，佶液上極めて酷似し て居ることを認めているが，雨者は全く网一なるの
ではないと推畣して居る。

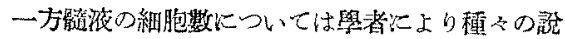
后なすすがするが，人体ではホルッマンの說は一

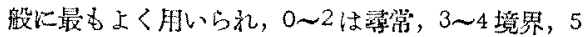

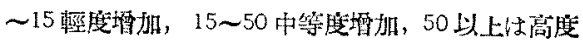

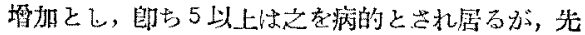

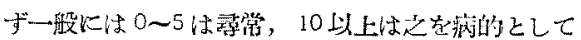

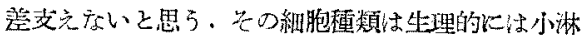

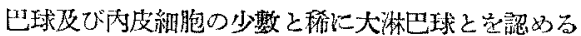
の双なりとされて届尚、又家鬼については1924年 䇺原道夫の 報告に上机ば0 5 の小湘巴球を生理的 ・とし, 只の後同じく1926年 Loebell 0 10,1932 年

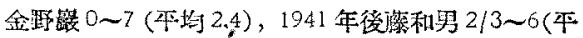
均 3.146)等參數の報告を見るが，先ず一般に0〜5

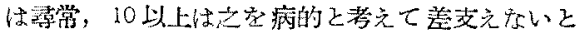

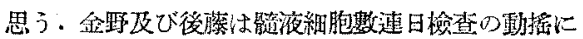

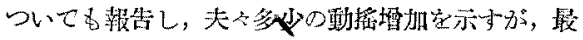

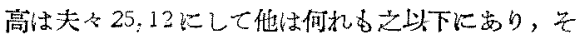

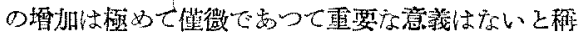
乙て居当。

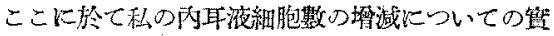

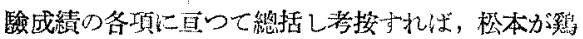

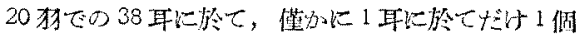

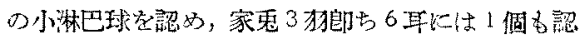

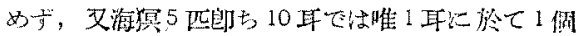

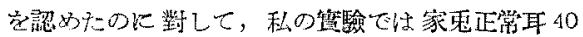

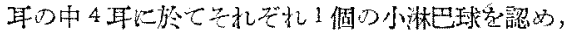

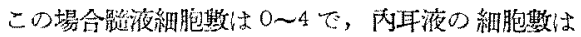

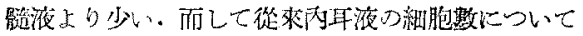

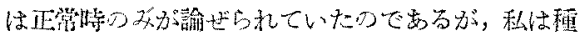

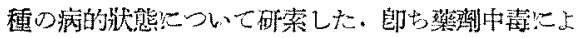

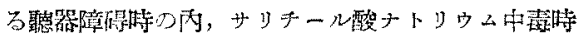

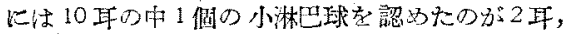

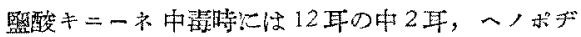

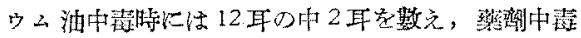
に拉ては內耳液細胞教は正常內耳液に比較して少し

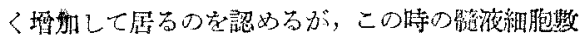

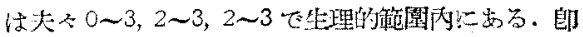

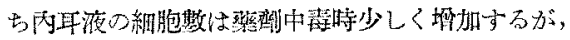

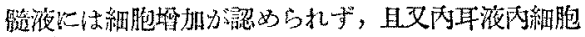
數は篧液程には澾しない。 
又アレルギーの場合には14耳の市3再於て1

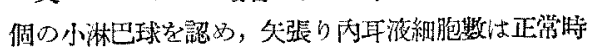

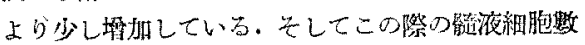

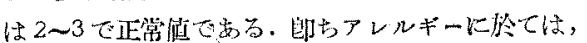

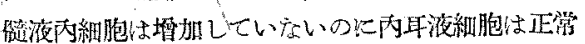

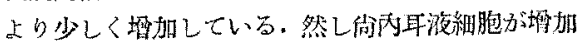

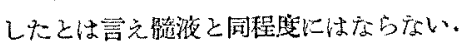

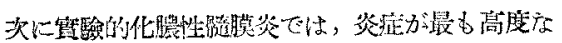

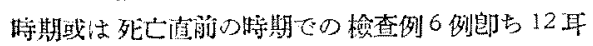

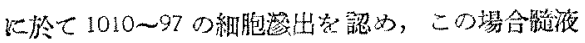

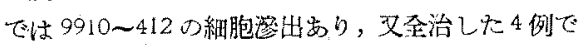

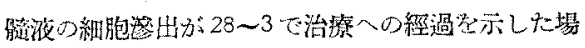

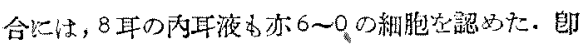

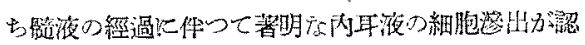

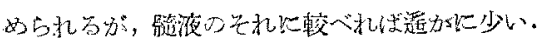

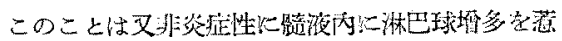

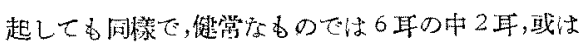

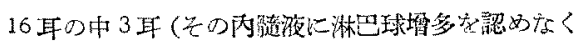

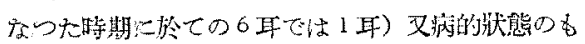

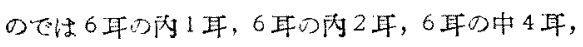

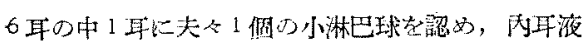

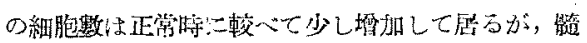

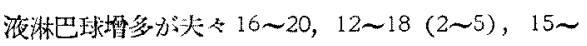

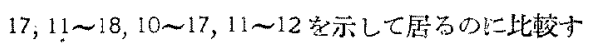

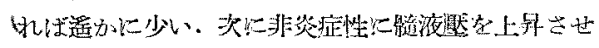

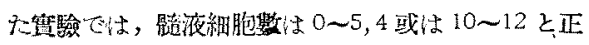

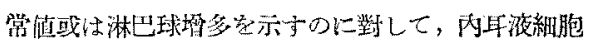
數は夫夫6耳の中1耳，6耳力中2耳，6耳の中 1 耳

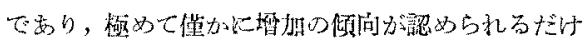
七专。

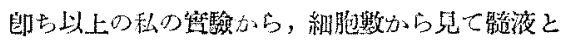

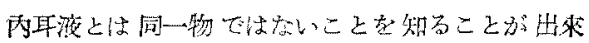

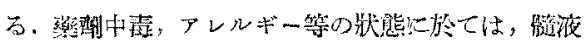

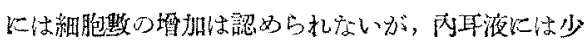

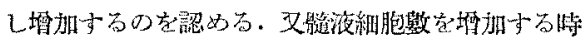

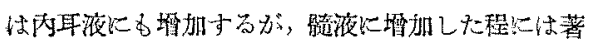

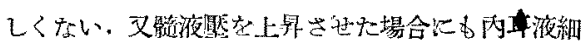

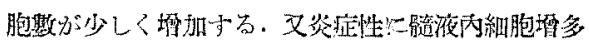

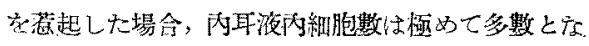

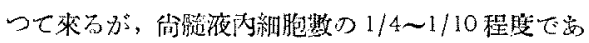
つて证して网程度とならない，從つて队耳液心細胞

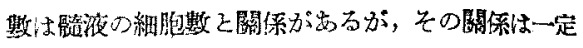

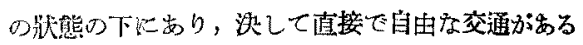

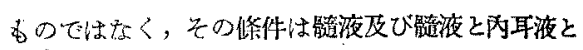

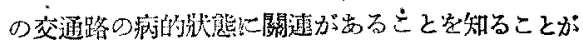
H來石。

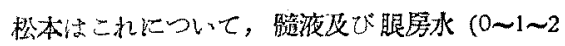

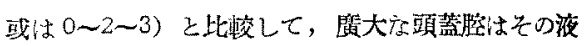

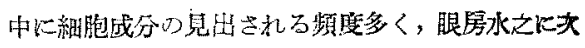

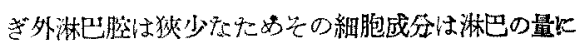

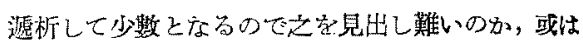

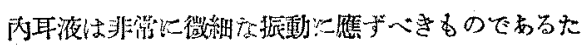

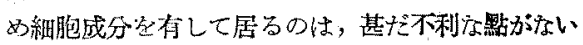

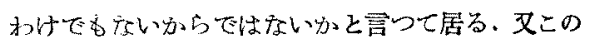

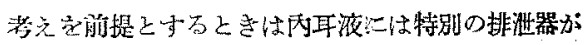

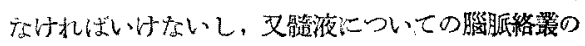

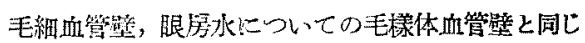

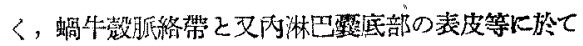

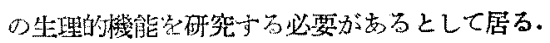

玟て1806 年者で 1881 年 Hyrtl，1869年 Schwa-

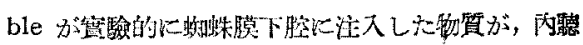

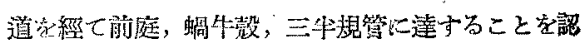

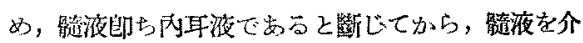

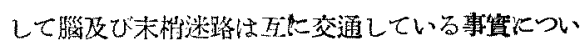

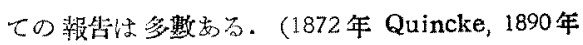
Stein brügge) 1877 年改び1879年 Webel-Liel は

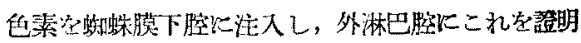

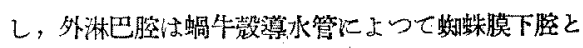
直接:こして自由な交通がある胆えた。1899年 Sie-

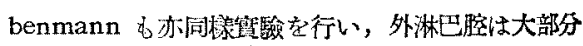

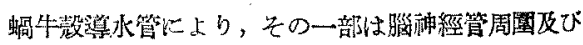

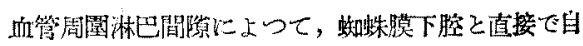
由交通名始るとした。1903年 Boehm u. Davi-

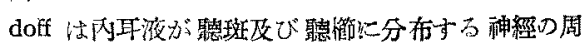

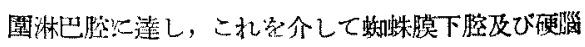

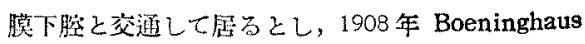

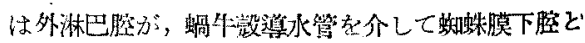

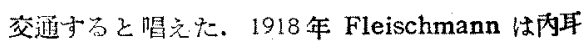

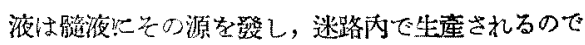

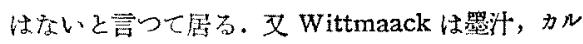

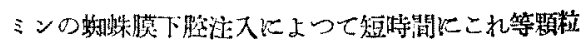

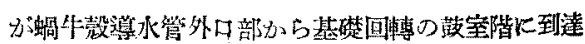


加治論交附圆

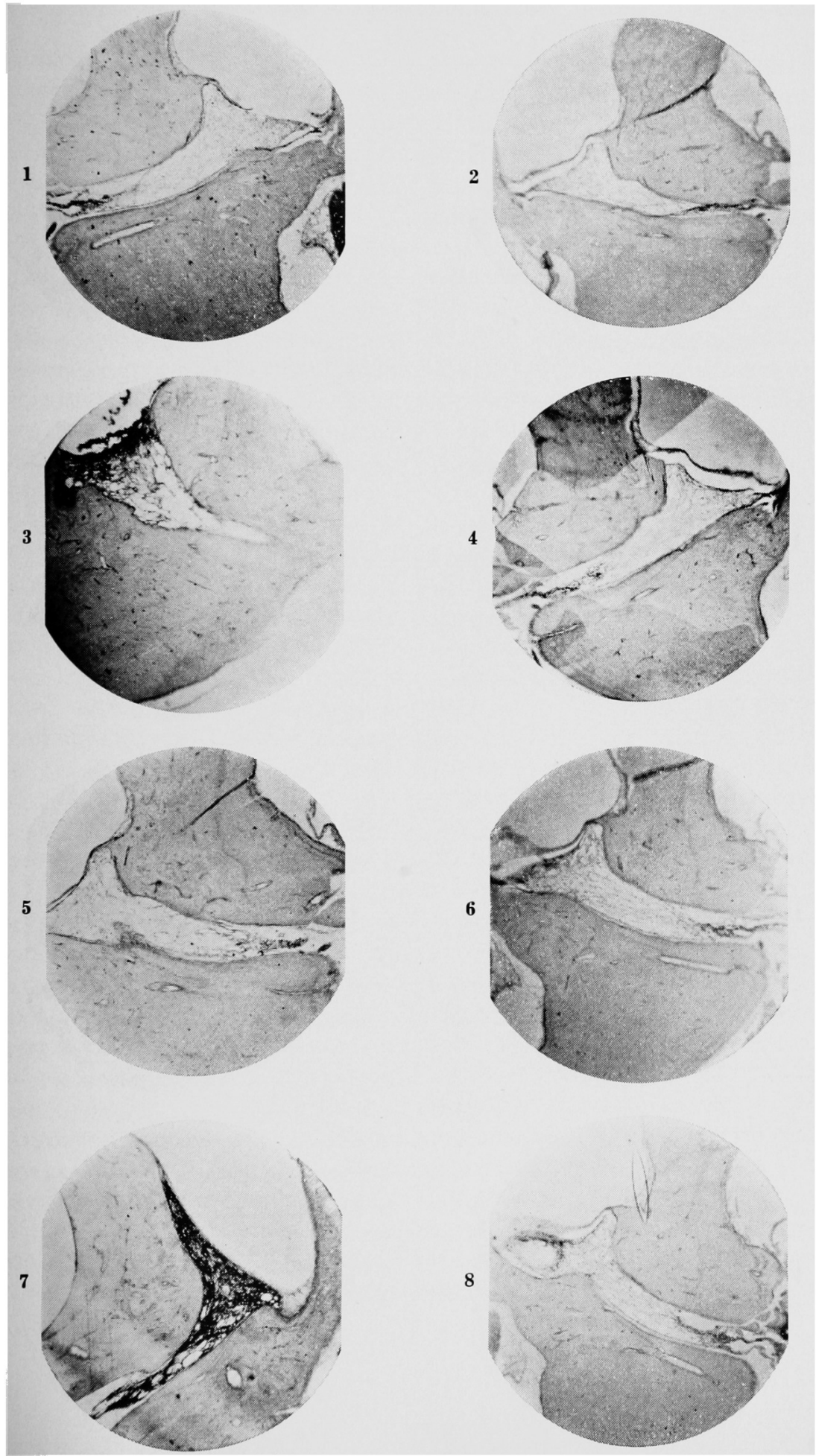


加治論交附圖
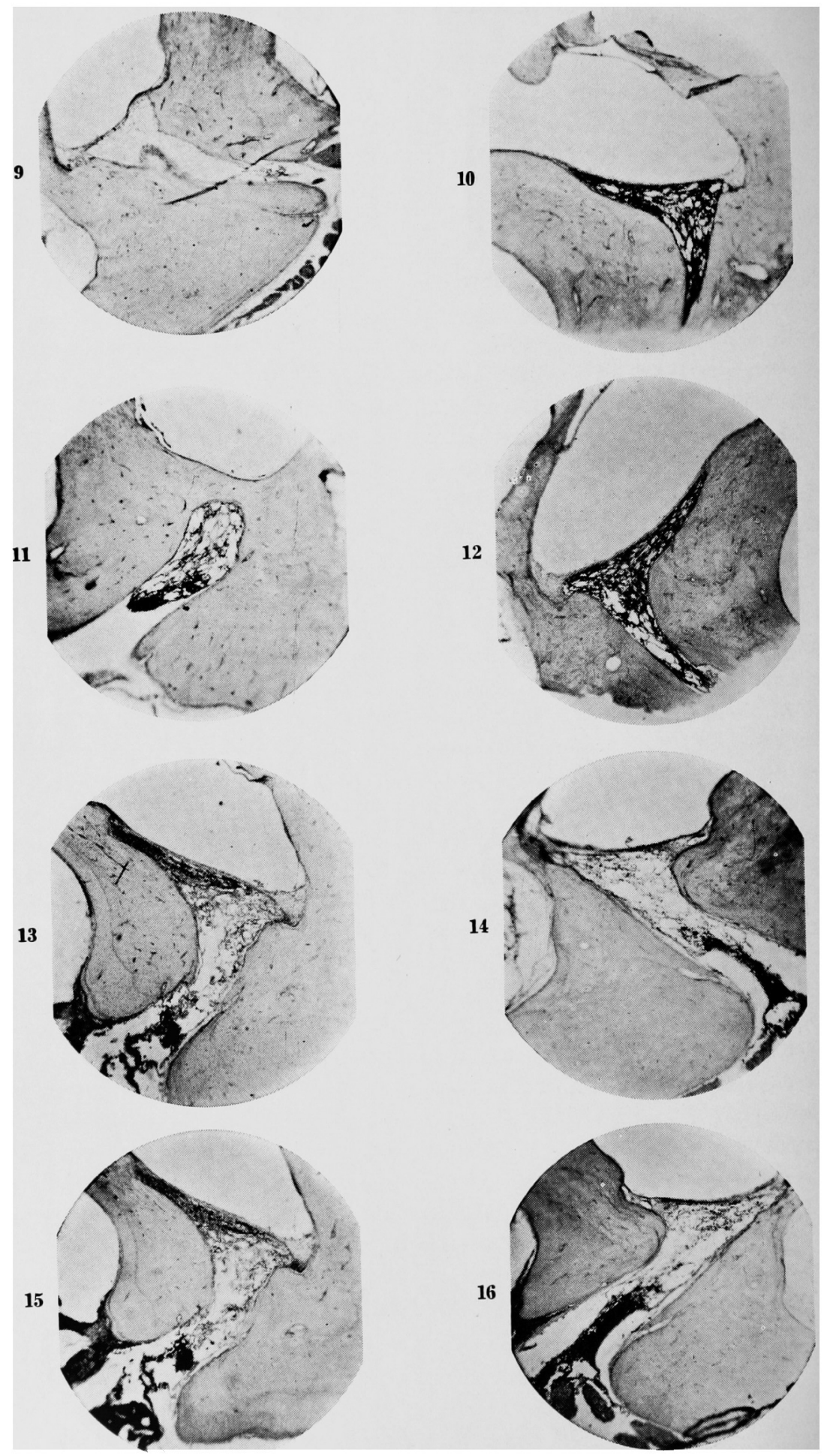
したのを認めた。

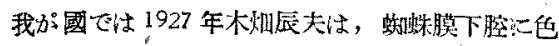

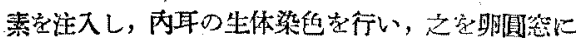

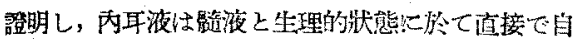

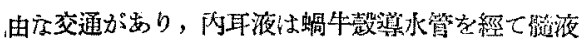

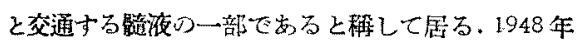

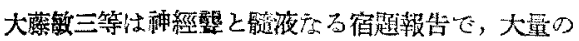

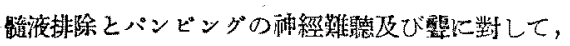

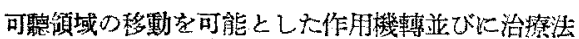

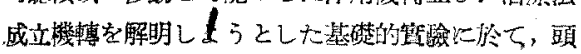

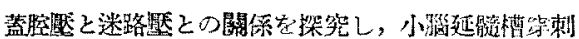

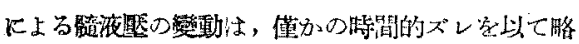

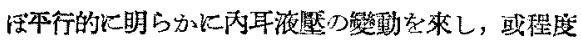

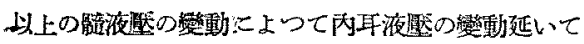
は外淋巴の流動が起り，內耳に形態的變化要認め，

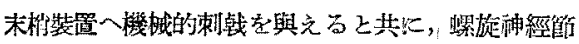

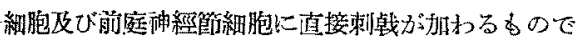

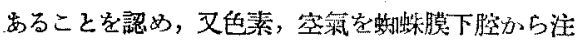
入して外森巴腔流入させ，或はとの这に流入させ

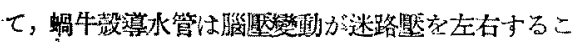
とが出來万徑路の主役をなすわので岕ること在否定

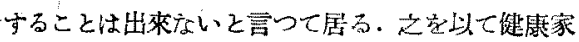

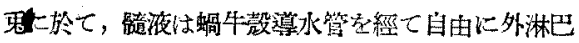

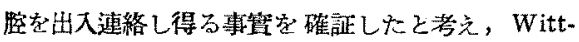

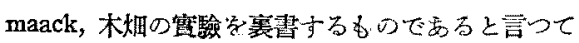
いる. 又內耳溜の屈折菜は Pulfrich 屈折計を以て

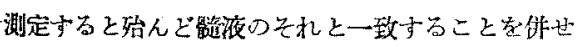

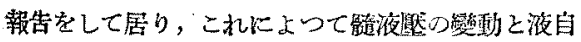

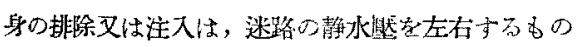
で，丙耳液は直接にこの影暨に暴露心れて居り，從

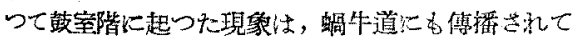

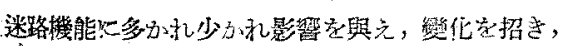

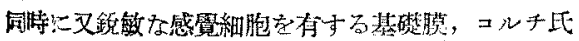

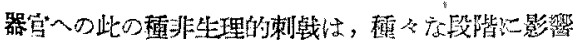
を與えらことは明白であるとしている。

Lかし1870年改び1875年，Key u. Retzius 等

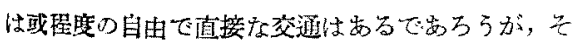
れではその肖由の度合，流動の方向々の他の群緗は 首肯することが出來ないとして，犬攻び家雭の蝴蛛

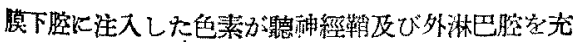

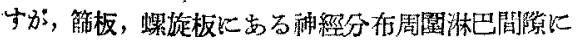

は達しないから，外淋巴腔と頭蓋朕との直接の交通

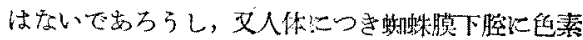

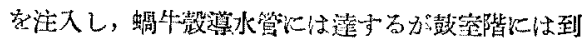

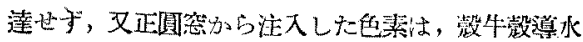

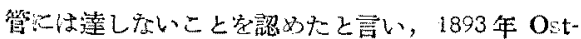

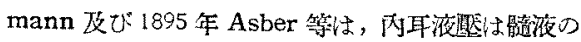

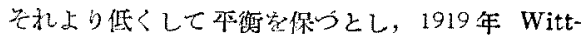

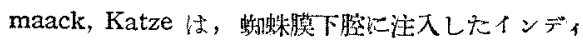

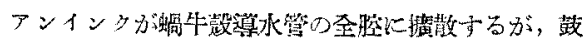

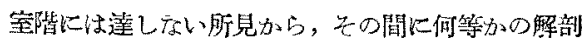

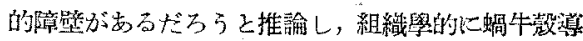

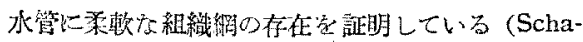
efer u. Giesswein はこれ等の組織維は完全厅障敬

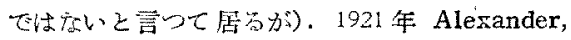

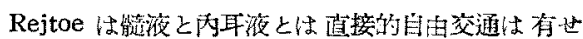

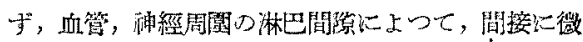
量交通家有术吉之言つて居当。1923年 Chilow 生

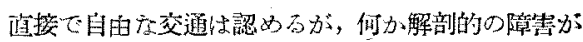

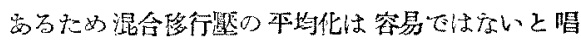

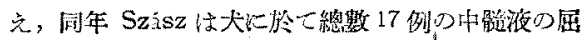

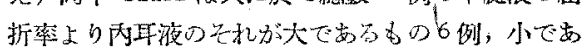

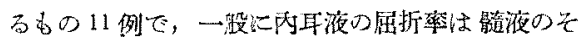

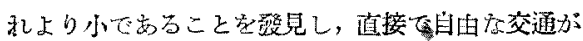

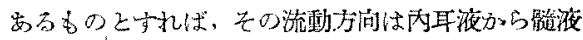
に何うで安ろうと諭じている。1924年 Karlefors

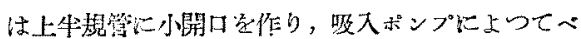

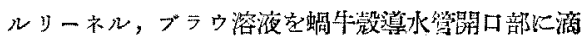

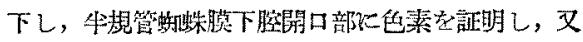
その逆む成功した。しかじによつて值接で自由

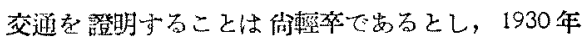

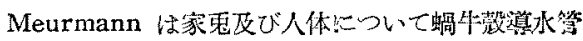
の生体染色と剖見を行つて，直接で自由交通は信 ずることが出来原いと言つて居る。

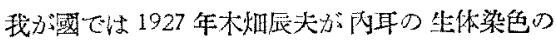

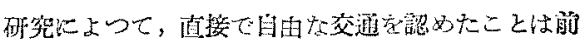

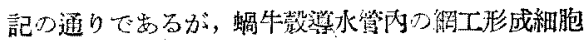

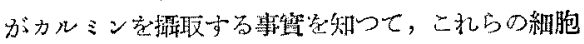

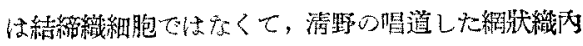
被細胞ではないかと推諭したのに始杰り，.1930年 田中政次螎牛款導水管の官能について矿究し, 蛤

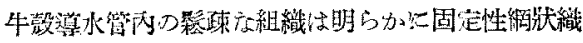




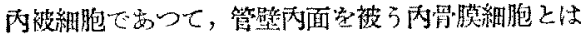
本照的に罢なるものであるとし，迷路炎に際しては

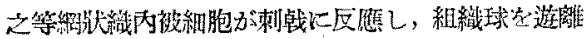

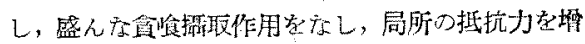

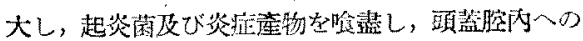

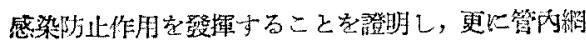

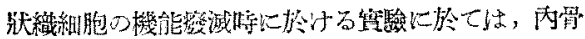

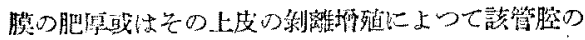

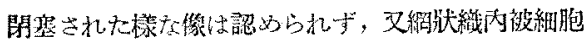
が存在しないために反應的に感染虎阻止する核な像

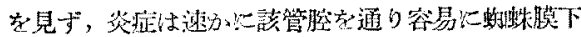

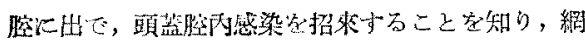

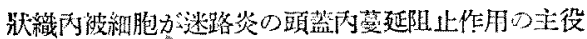

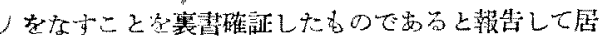

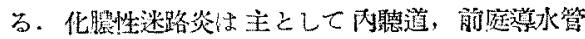

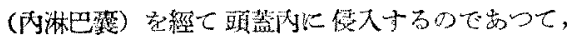

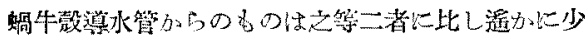
く，全く否定することは出來ない程度であると諭じ て居る。

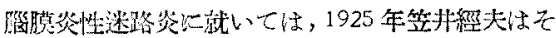

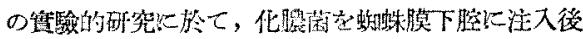

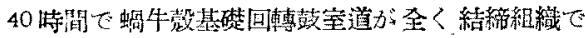

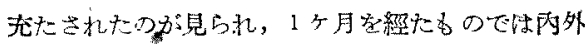

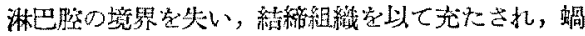

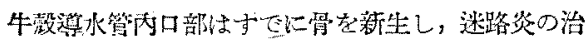

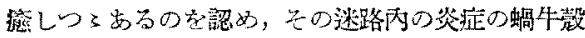
に最强て，㓣庭，牛规管之に次ぐことから透膜の炎

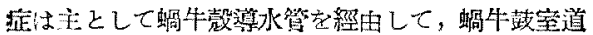

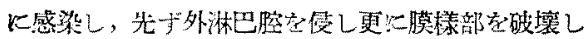

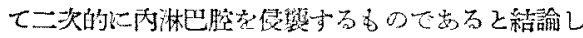
て居る.

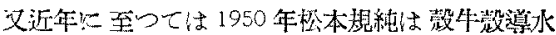

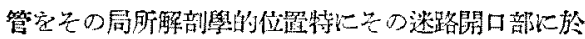

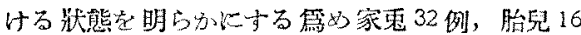

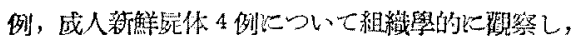

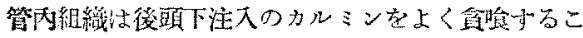

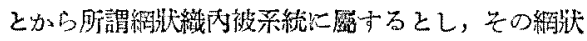
䋐維の大部分は迷路祭口部飞於て正圓空膜內面に結

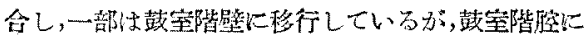

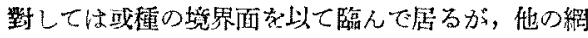
㓠織部分の構慥と同㧼であることを知り，又後頭下
注入咊汁の全哙狀態は外口部で最す旺盛で，內口部 に近ずくと共に減少しているが，鼓室階基碟回轉部

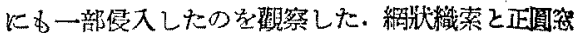

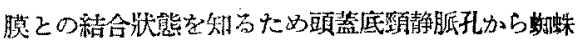

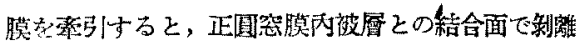

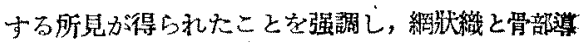
水管との間には一定の遊離間腔の存在を認めて居

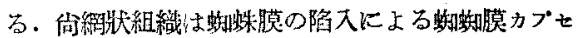
ルで包丸れ，その迷路端の一部は正圆空膜に密着し て居万とる唱气て居る.同し人松本は以上飞追加し

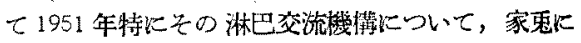

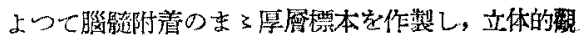
察を企て，その結果多極細胞笑起而び格子狀緎維の 重買だけによつて圆まれ，一般網腿上り稍大で瞵接

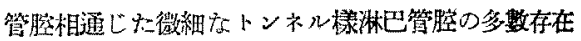

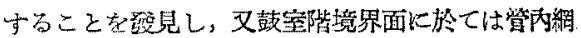
标組絨緗胞の一部が腔內へ少數放逸的に存在するこ。 とを認め，淋巴の交流はこの淋巴トンネルを通して 行わ机ると推公して居る. 文絹樣組織內:毛紐血管

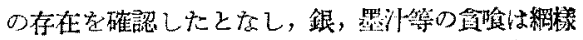
組織細胞によるものは悲く，主としてこの毛細血管 加5游出した白血球比上当々述心，從來管內赤血球

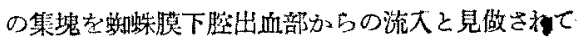
いたのは，この毛細血管の高度の搆張によるすのた

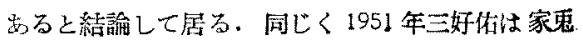

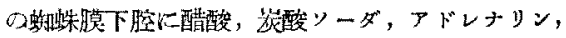
ピロカルピン皮びヒスタミンを注大し，蛹牛数㔍水

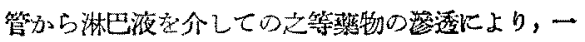

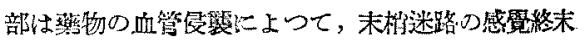
渂置の縮小儌又は膨大像高認めて居り，同年吉尾克 己は石松子未游液奴家東の後頭下胵に注大し，蝸

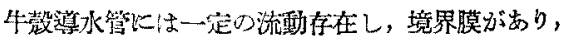

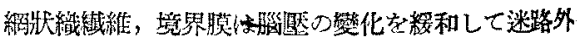
淋巴腔に傳える作用を有し，石松子末に上先症最

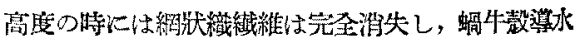

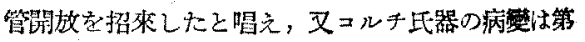
1，2 回博起始部が最す照著で，ライスネル氏膜には 㱠えど買常铝めずとしている，同年片木正雄は家

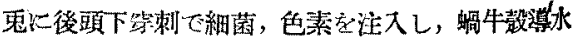

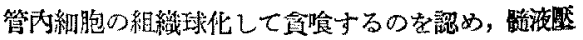

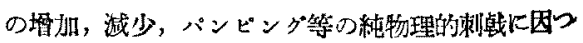


ても管灭細胞の組織球化圣知り，色素注入後パンビ

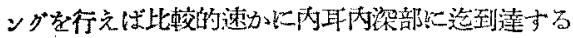

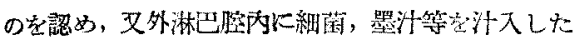

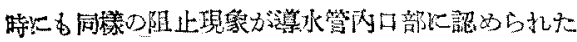

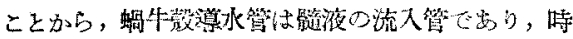

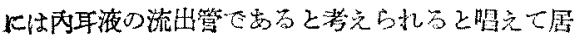

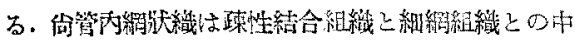

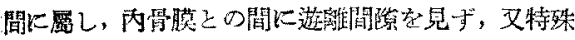

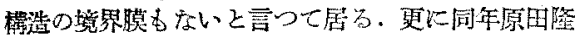

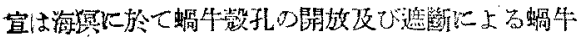

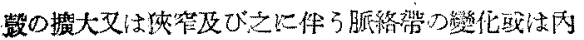

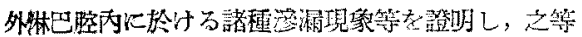

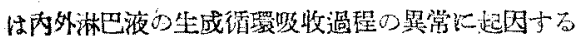
すのである論じて居る。

1948 年 Waltner の晿えた Barrier Membrane of Aquaeductus cochleae の馀傤飞は正引やく反

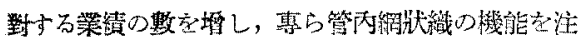
目されるに至つたが、同じく Waltner 及び Alt-

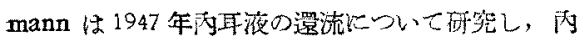

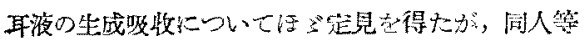

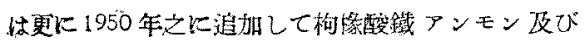

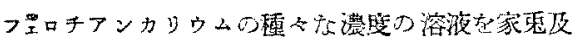

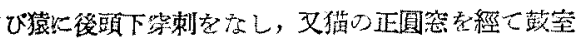
階に注入乙 Prussian blue 制粒の內耳の远状

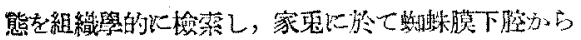

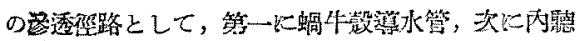

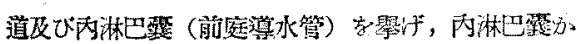

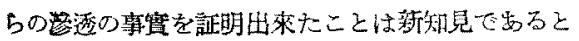

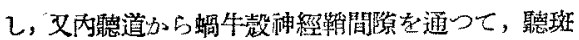

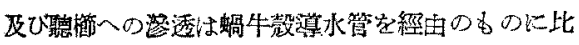
較すれば，極めて微量でとるに足らない之論じ，算

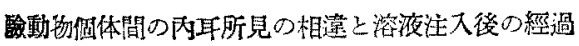
特間及び注入量との間飞は一定の閶係孛認めず，寧

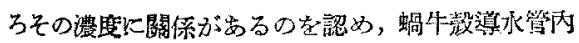

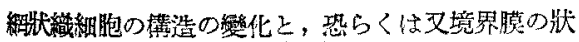

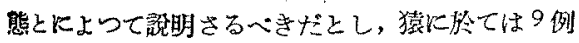

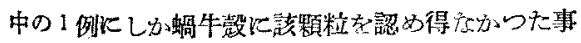

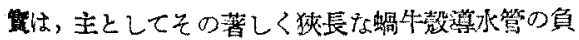

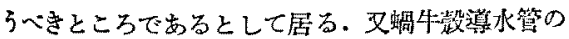

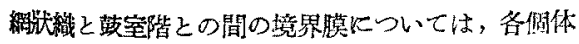
によつて種々な狀態を示すとなし，又全ての器酌に

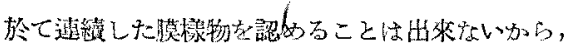

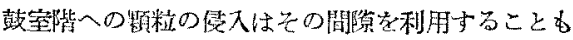
あり得学上唱之て居る。

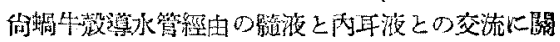

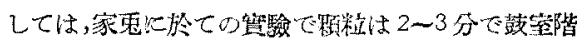

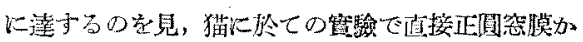

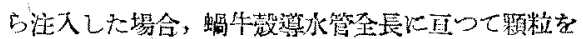

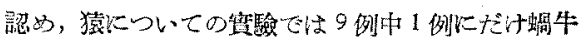

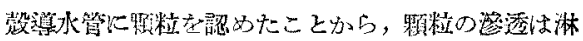

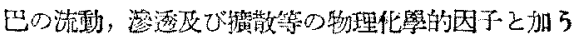

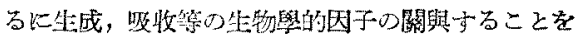

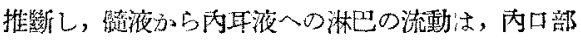

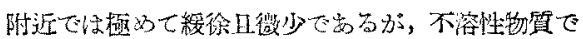

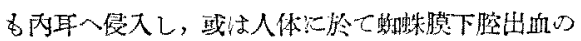

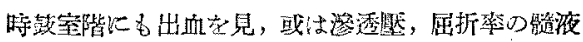

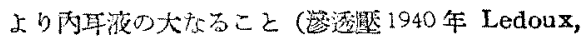

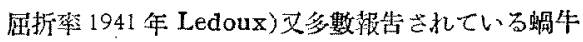

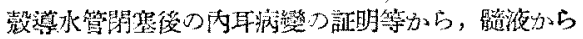

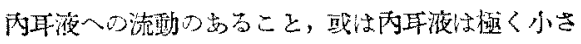

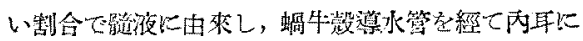
侵大したるのてあるか子知机と言うことは，明確

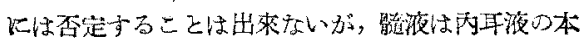

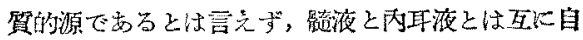

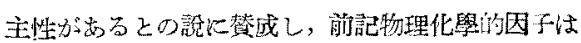

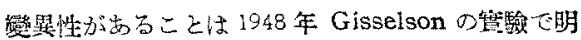

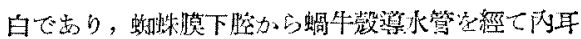

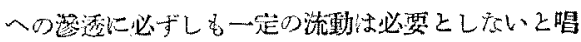

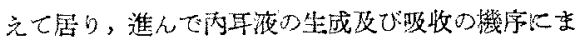
で翰及して居る。

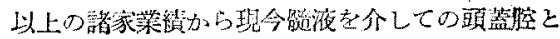

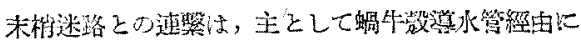

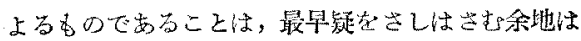
ないが相互間の湘巴の交流乃至流動に䦥しては，そ

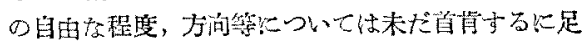

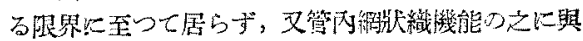
つて力出ることは，推定寸る北蜼なことてはな

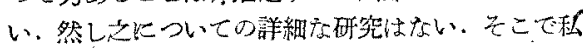

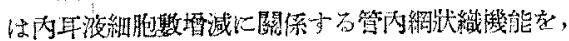

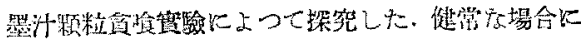

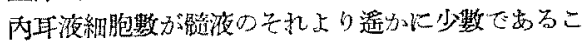

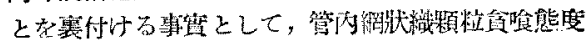

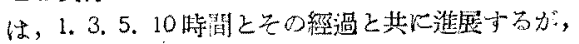




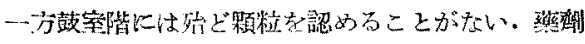

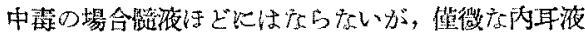

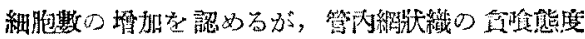

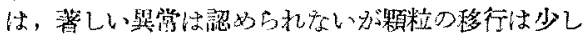

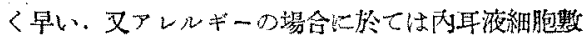

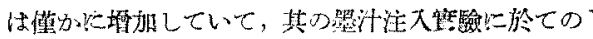

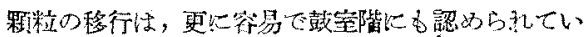

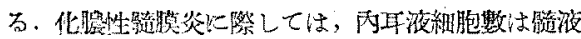

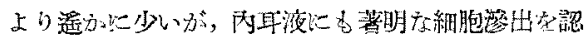

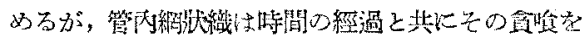

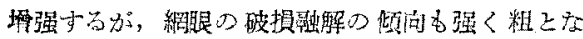

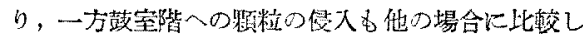

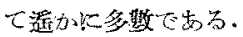

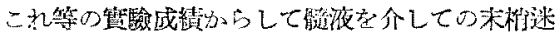

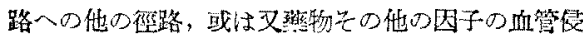

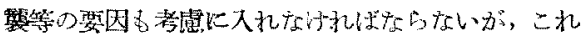

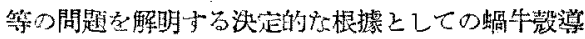

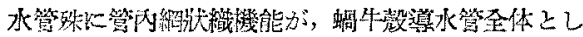

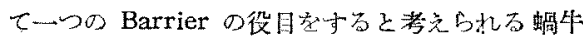

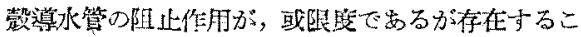

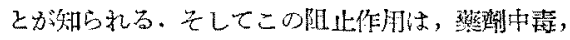

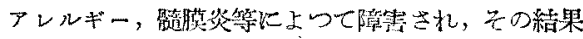

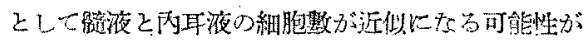
数及。

\section{第6 音 結論}

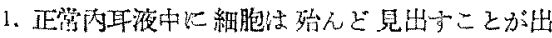

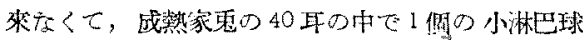

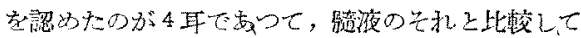

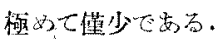

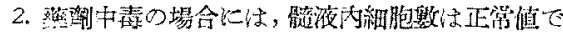

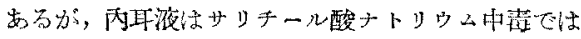

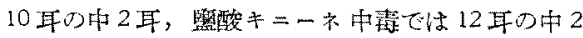

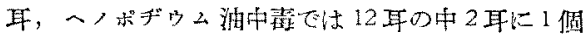

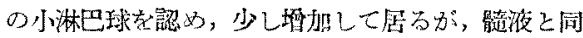

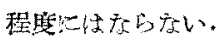

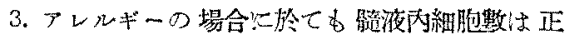

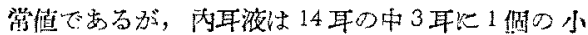

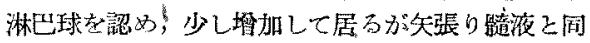

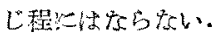

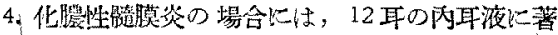

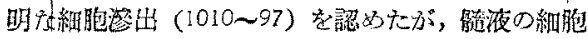

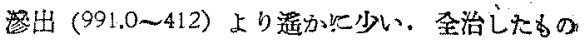

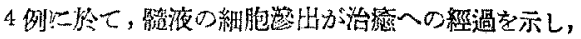

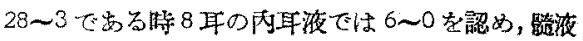

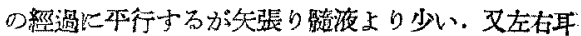

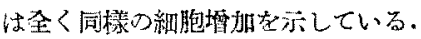

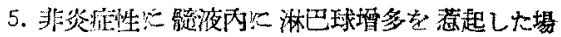

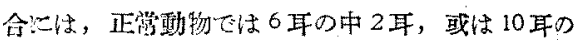

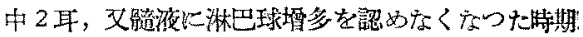

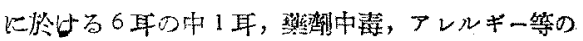
動物ではそれぞれ6耳の年1耳，6耳の中2耳，6耳 の中4耳，6耳の中1耳に夫《1個の小柶球觉認

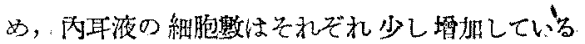

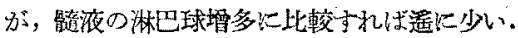

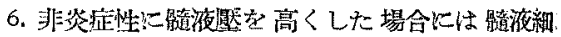

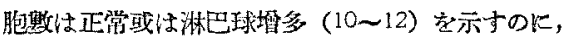
內耳液ではれぞれ6耳の中 1 耳，6耳の中2耳，

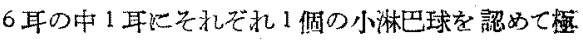

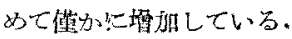

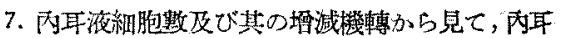

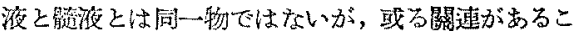

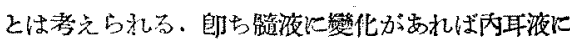

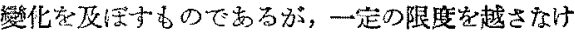
礼ば起り得ない。

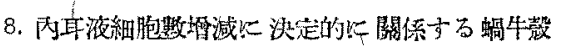

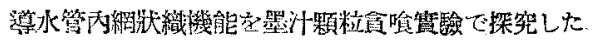

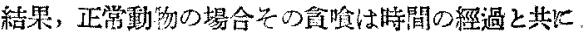

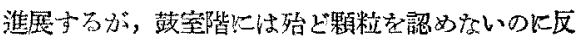

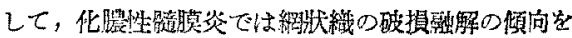

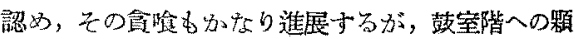

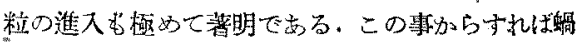

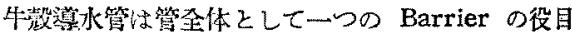

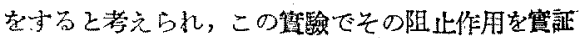
Lた.

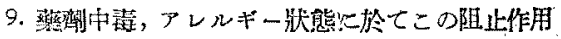

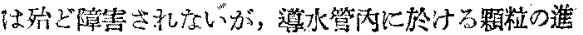

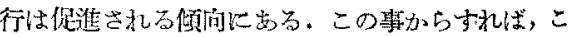

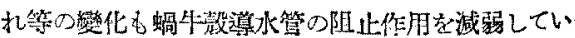
ると萢之る。

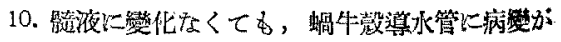

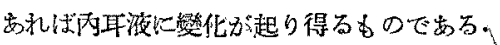




\section{琴考献}

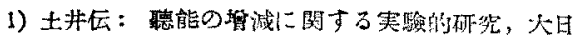

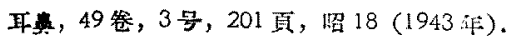

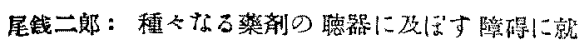

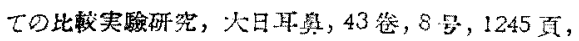
昭 12 (1937 年).

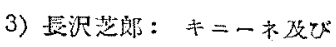

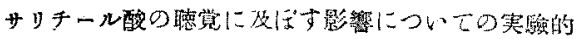

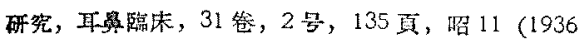
年).4）緒方周一：规那アルカ口イド䀧に因る

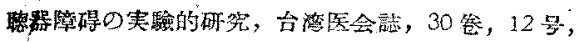

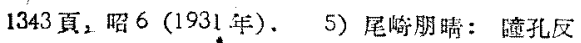

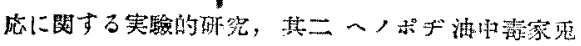

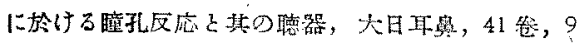

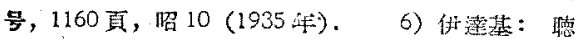

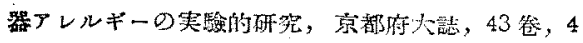

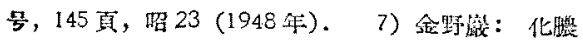

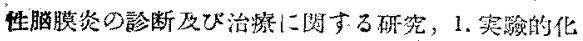

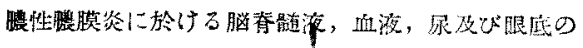

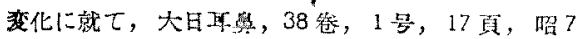

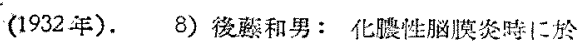

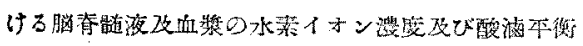

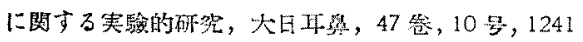

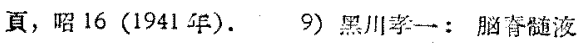
压並びに液內䒚削移行に関与る知見補潟，大日开

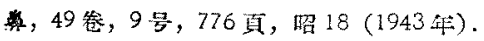

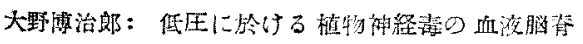

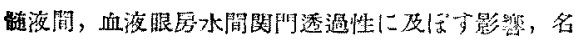

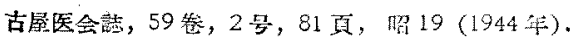
11) 笠原道走: Uber die normale cerebrosp:nal-flüssigkeit des Kaninchens Zeitschr. f. d, ges. neurol. u. psychiat. LXXXXIII s. 352.

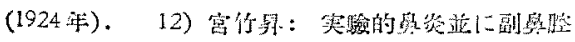

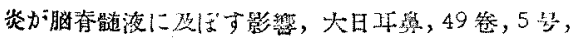
437 鿓，昭 18 (1943年)。

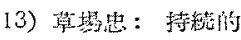

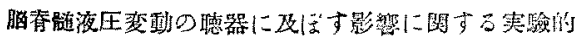

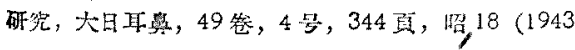

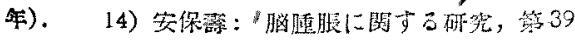

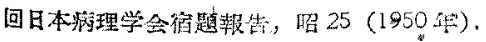

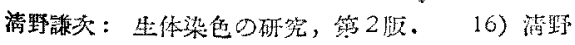

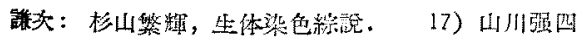

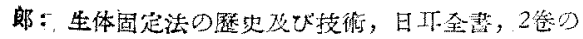

3, 422 面. 18) Fleischmann: Studien über die Herkunft des Labyrinthwassers Arch. f. Ohr. u.s.w. Bd. 120, s. 193 (1918 19) 坊

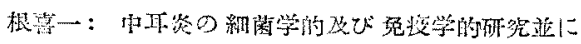

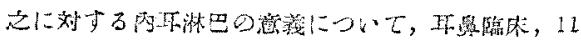

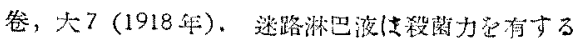

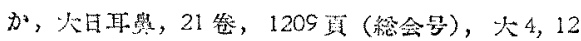

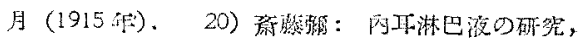

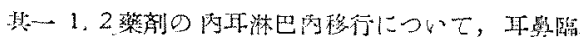

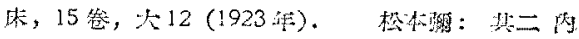

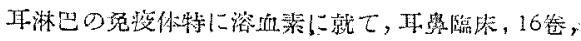

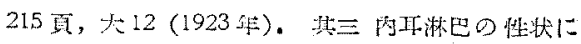

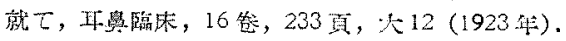

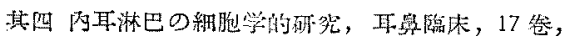

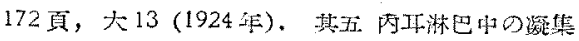

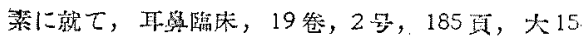

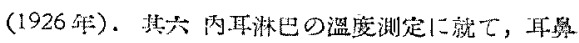

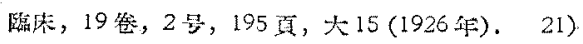

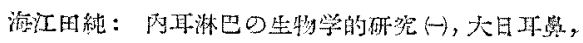

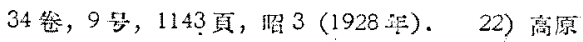

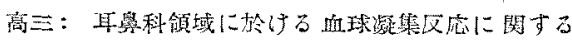

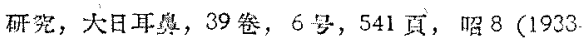

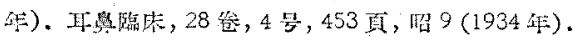

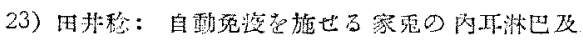

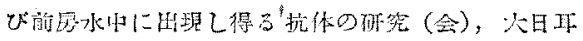

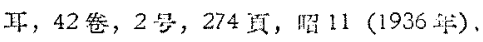

Webel-Liel: Experimentelle Nachweiss einer freien Kommunikation d, endo u. peri labyrinthischen Räumen des menschlichen Ohrlabyrinthes mit extralabyrinthischen intrakraniellen Räumen. Virchow's Archv. Bd.77, s. 207. (1879年). 25) Kartonoski: Vergleichende anatomischen Studien über dem Aquaecuuctus cochleae und über seine Beziehungen zum Subarachnoidealraum, des Gehirns. Monatschr. f. O. Jahr LXIV (19305). 26) 本烟庭决: Experimentelle Studies on the relation between the cerebrospinal and labyrin-

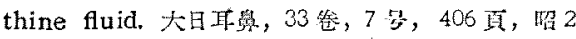

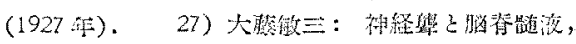

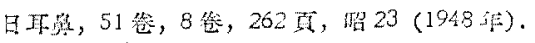


28) Szasz: Beiträge zur Labyrinth-Liquorfrage Zeitschr. f. H.N.O. Band 6, s. 256. (1923 45). 29) 决烟展犬：Die Vitale Farbstoff Aufspeicherung des Labyrinthes. 火曰IF 幽, 8昜, 597 页, 留2 (1927 作).

30) 田和政

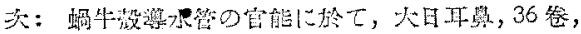

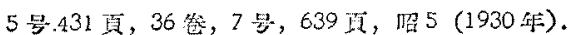

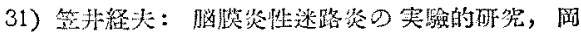
山医会詪，426号，火15 (1926年)，大日开悬，31 起，4号，546頁，大14 (1925 年)。 32) 松本规

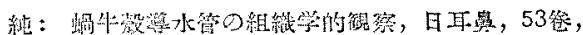

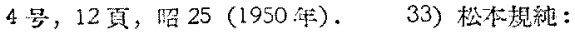

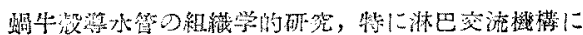

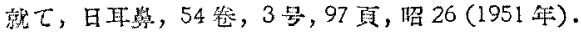

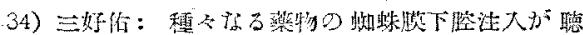

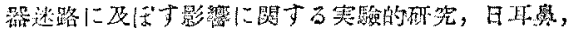

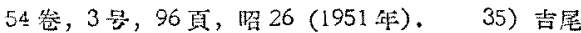

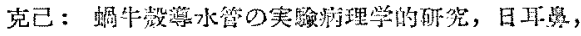

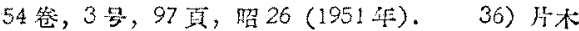

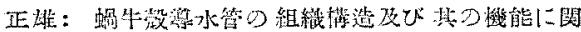

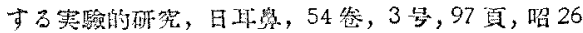

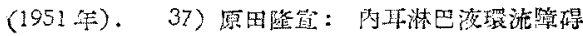

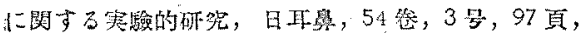

猬 26 (1951 茞).

38) Waltner, J.G.: Barrier Membrane of Cochlear Aquaeduct (Histologic Studies on Patency of Cochlear Aquaeduct) Archives of Otolaryngol. 47, 656. (1948 年), 39) Altmann, F. and Waltner, J.G.: The Circulation of the Labyrinthine Fluids. Annals of O.R. and L., 56, 684. (1947 4). 40) Altmann, $F_{r}$. and Waltner, J.G.: Further Investigations on the Physiology of the Labyrinthine Fluids. Annals of O.R. and L. 59, 657, (1950 年).

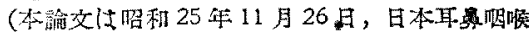
科学会整海堆方会复 10 回大会，昭和26年 4 月

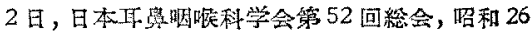

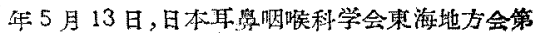
124 回例会及び昭租 26 年 5 月 20 日名古屋医学 会等61回総会に於て発㠇した）

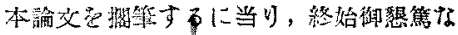

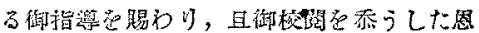

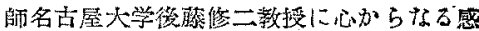

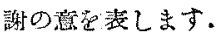

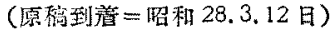

T. TAKAHUJI, M.D. AND G. HURUYA, M.D.: HEARING IMPAIRMENT AND ITS DEVELOPMENT CAUSED BY STREPTOMYCIN

\section{ストレプトーイシン投與後に発來せる聽力障害と 障害の進展過程に關する臨床的觀察}

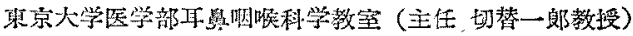

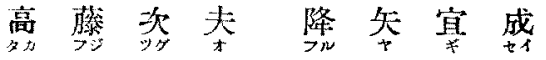

目次

1. 緒崖

II. 蛙例

II. A. 焋力障害

(1) 第1 辞の聼力

i) 代表僛,

ii）管 1 群の㯖力犁及文び矔㯖の
程度

(2) 第 2 样の聴力

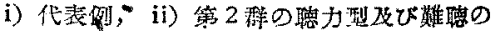
程宏

B. 㴔力变湖の追及，代表例 